\title{
Characterization of Pseudomonas bacteria of Piper tuberculatum regarding the production of potentially bio-stimulating compounds for plant growth
}

\author{
Danyllo Amaral de OLIVEIRA ${ }^{1,2}$, Solange da Cunha FERREIRA ${ }^{1,2}$, Daiany Larissa Ribeiro CARRERA ${ }^{1.3}$, \\ Cleyson Pantoja SERRÃO ${ }^{1,3}$, Daihany Moraes CALLEGARI ${ }^{1,2}$, Nicolle Louise Ferreira BARROS ${ }^{1,4}$, \\ Francinilson Meireles COELHO ${ }^{1,4}$, Cláudia Regina Batista de SOUZA ${ }^{1 *}$ (i) \\ Universidade Federal do Pará, Instituto de Ciências Biológicas, CEP 66075-110, Belém, PA, Brazil \\ Universidade Federal Rural da Amazônia, Programa de Pós-Graduação em Agronomia, CEP 66077-530, Belém, PA, Brazil \\ 3 Universidade Federal do Pará, Programa Institucional de Bolsas de Iniciação Cientíica-PIBIC-UFPA, CEP 66075-110, Belém, PA, Brazil \\ ${ }^{4}$ Universidade Federal do Pará, Programa de Pós-Graduação em Genética e Biologia Molecular, CEP 66075-110, Belém, PA, Brazil \\ * Corresponding author: bsouza@ufpa.br; (10) https://orcid.org/0000-0002-4028-5835
}

\begin{abstract}
Despite advances in the identification and characterization of endophytic bacteria in various plant species worldwide, little is known about such microorganisms in plants from the Amazon region. Previous studies reported that Piper tuberculatum endophytic Pseudomonas (isolates Pt12 and Pt13, identified as Pseudomonas putida and Pseudomonas sp., respectively) were able to inhibit the in vitro growth of Fusarium solani f. sp. piperis, which causes root rot in black pepper (Piper nigrum), and that Pt13 promoted the growth of P. nigrum. Therefore, the aim here was to characterize these bacteria regarding their ability to produce plant growth-promoting substances [siderophores, indol acetic acid (IAA) and soluble phosphate]. Chrome azurol $S$ assays were performed for the detection of siderophores. For qualitative and quantitative assays of IAA production and phosphate solubilization, Salkowski's reagent and NBRIP medium with molybdenum blue reagent, respectively, were used. Results revealed that Pt12 and Pt13 were able to synthesize IAA, mainly under a high concentration of L-tryptophan, indicating that they are IAA-producing bacteria, probably through a tryptophan-dependent biosynthesis pathway. The presence of $P$. nigrum extract positively influenced the IAA production by Pt12 and Pt13, with highest values of 125 and $90 \mu \mathrm{g} \mathrm{mL} \mathrm{L}^{-1}$, respectively. In addition, Pt12 was positive for the production of siderophores and produced $56.56 \mu \mathrm{g} \mathrm{mL}^{-1}$ of soluble phosphate. In contrast, Pt13 showed no ability to produce siderophores or to solubilize phosphate. Besides their potential in controlling plant diseases, Pt12 and Pt13 have potential as biofertilizers, favoring sustainable agriculture.
\end{abstract}

KEYWORDS: plant growth-promoting bacterial endophytes, IAA, siderophores, phosphate solubilization

\section{Caracterização de bactérias Pseudomonas de Piper tuberculatum quanto à produção de compostos potencialmente bioestimulantes para 0 crescimento de plantas}

\section{RESUMO}

Apesar dos avanços na identificação e caracterização de bactérias endofíticas em espécies vegetais em todo o mundo, pouco se sabe sobre esses microrganismos em plantas da região amazônica. Estudos anteriores mostraram que Pseudomonas de Piper tuberculatum (isolados Pt12 e Pt13, identificados como Pseudomonas putida e Pseudomonas sp., respectivamente) são capazes de inibir Fusarium solani f. sp. piperis, que causa a podridáo das raízes da pimenteira-do-reino (Piper nigrum), e que Pt13 promoveu o crescimento de $P$. nigrum. Portanto, o objetivo do presente trabalho foi caracterizar essas bactérias quanto à capacidade de produzir substâncias potencialmente bioestimulantes para o crescimento vegetal [sideróforos, ácido indol acético (AIA) e fosfato solúvel]. Ensaios de Cromo Azurol S foram realizados para detecção de sideróforos. Para os ensaios qualitativos e quantitativos de produção de AIA e solubilização de fosfato, foram utilizados o reagente de Salkowski e o meio NBRIP com azul de molibdênio, respectivamente. Os resultados revelaram que Pt12 e Pt13 sintetizaram AIA, principalmente sob alta concentração de L-triptofano, indicando que provavelmente utilizam uma via de biossíntese dependente deste aminoácido. A presença do extrato de P. nigrum influenciou positivamente a produçáo de AIA por Pt12 e Pt13, com valores máximos de 125 e $90 \mu \mathrm{g} \mathrm{mL} \mathrm{m}^{-1}$, respectivamente. Além disso, Pt12 foi positiva para produção de sideróforos e produziu $56.56 \mu \mathrm{g} \cdot \mathrm{mL}^{-1}$ de fosfato solúvel. Em contraste, Pt13 não produziu sideróforos, nem solubilizou fosfato. Além do potencial de controle de doenças de plantas, Pt12 e Pt13 têm potencial como biofertilizantes, favorecendo a agricultura sustentável.

PALAVRAS CHAVES: endófitos bacterianos promotores de crescimento de plantas, AIA, sideróforos, solubilização de fosfatos 


\section{INTRODUCTION}

Endophytic bacteria are able to colonize plant tissue without assuming pathogenic behavior or causing damage to the host plant (Hallmann et al. 1997). Several studies have demonstrated the potential of endophytic plant growthpromoting bacteria (PGPB), including those belonging to the genus Pseudomonas, in the promotion of plant growth by improvement of plant nutrition and disease control (Gaiero et al. 2013; Santoyo et al. 2016). In this context, microorganisms that can positively affect plants have emerged as a powerful tool for sustainable agriculture to replace chemical pesticides and industrial fertilizers, which can drastically contaminate the environment.

PGPB may employ direct and indirect mechanisms to promote plant development. Indirect mechanisms involve the inhibition of the growth of phytopathogenic organisms through the production of antibiotic compounds, lytic substances that degrade the cell wall, nutritional competition and via induction of host plant systemic resistance. On the other hand, direct mechanisms act by facilitating nutrient acquisition and production of substances beneficial to plants, such as nitrogen fixation, phosphate solubilization, iron sequestration by siderophore production, and phytohormone production (Glick 1995; Glick 2012; Beneduzi et al. 2012; Olanrewaju et al. 2017).

Using direct mechanisms, PGPB may favor plant development in three distinct ways: a) phytostimulation by indol acetic acid (IAA) production, which may improve the plant root system and induce the hardening of cell walls, forming a barrier to the entry of the pathogen in plant tissues; b) biofertilization, such as the ability to solubilize phosphorus and make it available to the plant, which may aid in increased agricultural production; and c) biocontrol, for example, in bacterial siderophore production, whose potential in iron nutrition antagonism inhibits the development of other microorganisms (Glick 1995; Glick 2012; Beneduzi et al. 2012; Olanrewaju et al. 2017).

Regarding the detection and quantification of plant growth substances produced by PGPB, suitable methodologies described in the literature have been used in the characterization of many bacterial strains. These methodologies involve the in vitro growth of bacterial strains in specific culture media, which, by colorimetric analysis, are able to quantify the production of these substances (Gordon and Weber 1951; Schwyn and Neilands 1987; Bric et al. 1991; Nautiyal 1999).

Despite advances in the identification of endophytic bacteria in a number of plant species worldwide (Hallmann et al. 1997; Gaiero et al. 2013; Santoyo et al. 2016), few studies have reported such microorganisms in plants from the Amazon region (Coelho et al. 2011; Nascimento et al. 2015; Chalita et al. 2019). As examples of bacteria with the potential to contribute to sustainable agriculture, Pt12 and Pt13, identified as Pseudomonas putida and Pseudomonas sp., respectively, were isolated from roots of Piper tuberculatum Jacq. (Nascimento et al. 2015), a Piperaceae species occurring in the Amazon region with known resistance to Fusarium solani f. sp. piperis, which causes root rot in black pepper (Albuquerque et al. 2001).

Black pepper (Piper nigrum L.), which originated in southern India and is known as "the king of spices", is a crop with social and economic importance worldwide. In Brazil, the main producer is Pará State in the north, where root rot disease has caused significant losses in this crop yield. Besides, susceptibility to root rot disease has been found in all 35 black pepper cultivars of the germplasm collection available in Brazil (Albuquerque et al. 2001). According to Nascimento et al. (2015), Pt12 and Pt13 bacteria were able to inhibit in vitro fungal growth at $38.96 \%$ and $55.31 \%$, respectively. A search for Pt12 genes involved in the production of antifungal compounds revealed sequences potentially related to phenazine biosynthesis (PhzF) (Silva Junior et al. 2018). In addition, recent studies confirmed Pt 13 as a PGPB of $P$. nigrum plants, since bacterial inoculation caused increased net $\mathrm{CO}_{2}$ assimilation rate and total chlorophyll content, as well as increased specific leaf area, total leaf area, root dry mass and total dry mass, in comparison to the control plants (Pereira et al. 2019). However, there has been no investigation into the ability of Pt12 and Pt13 to produce plant growth-promoting substances so far. Therefore, here we aimed to characterize these bacteria regarding the production of compounds that could contribute to the inhibition of fungal growth and promotion of plant growth.

\section{MATERIAL AND METHODS}

\section{Pseudomonas Pt12 and Pt13 culture}

We used Pt 12 and Pt13 bacteria, previously isolated from roots of Piper tuberculatum Jacq. plants and identified as Pseudomonas putida and Pseudomonas sp., respectively, based on their 16S rRNA gene sequences [Accessions JF900611 and JF900612 of GenBank (National Center for Biotechnology Information-NCBI)] by Nascimento et al. (2015). The bacterial cells were stored at $-20^{\circ} \mathrm{C}$ and $-70^{\circ} \mathrm{C}$ at the Institute of Biological Sciences of Universidade Federal do Pará (Belém, Pará state, Brazil). Bacteria were cultured in LB (Luria Bertani) broth and TS (tryptic soybean) broth (both from Himedia, India), depending on the experiments performed.

\section{Siderophore production}

For the detection of siderophores produced by Pt12 and Pt13 bacteria, we performed CAS (Chrome azurol S) agar medium assays, according to the methodology described by Schwyn and Neilands (1987). Bacteria were cultured in LB broth, with incubation at $28^{\circ} \mathrm{C}$ under agitation (150-200 rpm) for five days, with samplings at 24, 72 and $120 \mathrm{~h}$, with three repetitions at each time. As negative control, we used 
LB broth with no bacterium inoculation. After centrifugation of samples at 10,000 rpm for 10 minutes, $100 \mu \mathrm{L}$ of each supernatant were added to $10 \mathrm{~mm}$ diameter wells on CAS agar medium, followed by incubation at room temperature in the absence of light for $48 \mathrm{~h}$. Samples with the formation of a yellow-orange halo around the wells were considered positive for the production of siderophores.

For the quantification of siderophores produced by Pt12 and Pt13 bacteria, we used CAS solution according to the methodology described by Schwyn and Neilands (1987). Bacteria were cultured in LB broth for five days, with samplings at 24, 48, 72, 96 and $120 \mathrm{~h}$, with three repetitions at each time. As negative control, we used LB broth with no bacterium inoculation. After centrifugation of samples at $10,000 \mathrm{rpm}$ for 10 minutes, $0.5 \mathrm{~mL}$ of supernatant from each culture was mixed with $0.5 \mathrm{~mL}$ of the CAS solution, followed by evaluation of absorbance at 630 nanometers (nm), using a UV/VIS spectrophotometer, 30 minutes later. The number of siderophores was determined by the percentage reduction in the blue color of the solution in units of siderophores (SU\%) compared to the negative control. The number of siderophores was calculated by the formula: $\mathrm{SU} \%=[(\mathrm{Ar}-\mathrm{A})$ / Ar] x 100, where AR is the reference absorbance at $630 \mathrm{~nm}$ (CAS solution + medium without bacterial inoculation) and A is the absorbance of the sample (CAS solution + supernatant).

\section{IAA production and bacterial growth curves}

For the detection of IAA produced by Pt12 and Pt13, we used the methodology of Bric et al. (1991), with one adaptation: in addition to the concentration of $1 \mathrm{~g} \mathrm{~L}^{-1}$ of L-tryptophan, we also used TS agar medium containing the amino acid at $3 \mathrm{~g} \mathrm{~L}^{-1}$. Thus, bacteria were streaked on TS agar medium containing L-tryptophan at $1 \mathrm{~g} \mathrm{~L}^{-1}$ and 3 $\mathrm{g} \mathrm{L}^{-1}$ and covered with nitrocellulose membrane. After 48 $\mathrm{h}$ of bacterial growth at room temperature, nitrocellulose membranes were removed, treated with $2.5 \mathrm{~mL}$ Salkowski reagent $\left(1.2 \% \mathrm{FeCl}_{3}\right.$ and $\left.37 \% \mathrm{H}_{2} \mathrm{SO}_{4}\right)$ and kept in the dark for 20 minutes, followed by evaluation regarding the presence of pink coloration around the bacterial colonies.

For the quantification of IAA produced by Pt12 and Pt13, the colorimetric methodology described by Gordon and Weber (1951) was used with two concentrations of L-tryptophan supplemented in TS broth [(TS-Trp); $\left(0.2 \mathrm{~g} \mathrm{~L}^{-1}\right.$ and $\left.3 \mathrm{~g} \mathrm{~L}^{-1}\right)$ ]. Bacteria were cultured in TS-Trp with samplings at $6,12,24,48,72,96$ and $120 \mathrm{~h}$, with three repetitions at each time. As negative control, we used TS-Trp with no bacterium inoculation. After centrifugation of samples at $10,000 \mathrm{rpm}$ for 10 minutes, the supernatant was collected. Salkowski reagent was added to the supernatant samples, at a 2:1 ratio, followed by incubation in the absence of light for 20 minutes. The absorbance at $530 \mathrm{~nm}$ for each sample was determined using a UV/VIS spectrophotometer. The concentration of IAA was estimated using a standard curve based on known concentrations of authentic 3-indolacetic acid (Sigma-Aldrich, USA) diluted in TS broth and their correspondent values of absorbance at $530 \mathrm{~nm}$, in comparison to those found in the bacterial samples.

The above assays were also conducted in the presence of a plant extract, in order to stimulate the production of IAA by bacteria in TS-Trp. An aqueous extract of Piper nigrum was prepared according to Jasim et al. (2014). Stem, root and leaf tissues were macerated in aqueous solution, filtered on paper filters, followed by filtration on $0.45 \mu \mathrm{m}$ membrane filter. Plant extract was used at $0.5 \%(\mathrm{v} / \mathrm{v})$ in TS-Trp $(0.2 \mathrm{~g}$ $\mathrm{L}^{-1}$ and $\left.3 \mathrm{~g} \mathrm{~L}^{-1}\right)$.

Thus, the IAA quantification was determined in two concentrations of L-tryptophan $\left(0.2 \mathrm{~g} \mathrm{~L}^{-1}\right.$ and $\left.3 \mathrm{~g} \mathrm{~L}^{-1}\right)$ and in the absence (Pt12 and Pt13) and presence (Pt12ext and Pt13ext) of P. nigrum extract. The treatments were compared at each sampling time $(6,12,24,48,96$ and $120 \mathrm{~h})$, with three repetitions per treatment at each time.

Since it is known that tryptophan may interfere in bacterial growth (Brandenburg et al. 2013), we estimated Pt12 and Pt13 growth curves with bacteria cultured in TS broth and TS broth with $3 \mathrm{~g} \mathrm{~L}^{-1}$ of L-tryptophan. Bacteria were cultured for 5 days, with samplings at 2-hour intervals for the first 12 hours, followed by samplings at 4-hour intervals up to 120 hours of growth. The bacterial growth was monitored by optical density (OD) measurements at $600 \mathrm{~nm}$, based on the absorbance values of the samples that were determined using a UV/VIS spectrophotometer.

\section{Phosphate solubilization}

For the evaluation of phosphate solubilization, Pt12 and Pt13 were cultured in TS broth at $28^{\circ} \mathrm{C}$ under agitation (150-200 rpm) for 12 hours. As negative control, we used TS broth with no bacterium inoculation. Samples containing 1 $\mathrm{mL}$ of culture were centrifuged at 12,000 rpm for 20 minutes; the bacterial pellets were washed three times in distilled and autoclaved water, followed by their resuspension in $1 \mathrm{~mL}$ of water. In triplicates, samples containing $100 \mu \mathrm{l}$ of washed bacterial cells (or the negative control) were added to $10-\mathrm{mm}$ diameter wells on NBRIP agar medium supplemented with $5 \mathrm{~g}$ $\mathrm{Ca}_{3}\left(\mathrm{PO}_{4}\right)_{2}$ per liter of medium, according to Nautiyal (1999), in order to verify the formation of transparent halos around the wells. The size of the formed halos was measured seven days after the bacterial inoculation, and the measurements were used to calculate the solubilization index [IS $=$ (halo diameter + culture diameter) / culture diameter], according to Nguyen et al. (1992).

To quantify phosphate solubilization, we used NBRIP medium supplemented with $\mathrm{Ca}_{3}\left(\mathrm{PO}_{4}\right)_{2}\left(5 \mathrm{~g} \mathrm{~L}^{-1}\right)$, but with no addition of agar. Samples containing $200 \mu$ of washed bacterial cells (or negative control) were added into $10 \mathrm{~mL}$ of NBRIP medium and incubated at $28^{\circ} \mathrm{C}$ under agitation 
at 150-200 rpm for four days, with samplings at 24, 48, 72 and $96 \mathrm{~h}$, with three repetitions at each time. All samples had their $\mathrm{pH}$ measured, and the supernatant produced after two centrifugations (12,000 rpm for 15 minutes) was used in a 1:5 ratio in reaction with the blue molybdenum method solution (Murphy and Riley 1962) in order to quantify solubilized phosphorus. After 10 minutes of reaction with blue molybdenum solution, the absorbance was determined at $882 \mathrm{~nm}$ using a UV/VIS spectrophotometer. The amount of soluble phosphorus was determined by the difference between the absorbance values of the control and the absorbance of the treatments compared to the standard curve, made from known concentrations of $\mathrm{KH}_{2} \mathrm{PO}_{4}\left(70 \% \mathrm{PO}_{4}^{-}\right)$reacted with the phosphorus detection solution and determined at $882 \mathrm{~nm}$ after 10 minutes of reaction.

\section{Data analysis}

Data obtained from production of IAA, siderophores and soluble phosphate by Pt12 and Pt13 were evaluated using the statistical software R-Studio v. 1.1.456. Variance analysis (ANOVA) was performed with the "ExpDes.pt" package. For each IAA experiment $\left(0.2 \mathrm{~g} \mathrm{~L}^{-1}\right.$ and $3 \mathrm{~g} \mathrm{~L}^{-1}$ of L-tryptophan), the mean values of IAA production from different treatments (Pt12, Pt12ext, Pt13 and Pt13ext) were compared within each sampling time $(6,12,24,48,72,96$ and $120 \mathrm{~h})$ using the SNK test with significance level of $\mathrm{p}<0.01$. The graphics were generated using the "Ggplot2" package. Data of siderophores and soluble phosphate production by Pt12 and Pt13 at each sampling time $(24,48,72,96$ and $120 \mathrm{~h})$ were expressed as the mean \pm standard error.

\section{RESULTS}

\section{Siderophore production}

In the CAS agar medium assays, the yellow-orange halo formation was visualized only for Pt12, with supernatant samples collected at 24,72 and $120 \mathrm{~h}$ showing positive for the production of siderophores. In contrast, the Pt13 isolate showed no ability to produce siderophores in the experimental conditions used herein (Figure 1). Likewise, results of quantitative evaluation using CAS solution confirmed that siderophore production occurred only with Pt12, with SU\% ranging from 19.69 to 31.02 for samples collected at 24 and $120 \mathrm{~h}$ (Table 1).

\section{IAA production}

Pt12 showed a stationary growth phase at OD (optical density) 2.5 from 40 to 120 h (Figure 2a), while Pt13 presented a biphasic pattern similar to diauxic growth (biphasic exponential growth intermitted by a lag phase at 10 to $60 \mathrm{~h}$ with OD 1.5 and a stationary phase at 78 to $120 \mathrm{~h}$ with OD 2.5) (Figure 2b). The presence of $3 \mathrm{~g} \mathrm{~L}^{-1}$ of L-tryptophan in the TS broth decreased the growth of both bacteria (Figure
2). Pt13 was more susceptible to the amino acid effect, with samples from $6 \mathrm{~h}$ to $120 \mathrm{~h}$ decreasing below OD 1.5, while Pt12 growth was influenced less with samples decreasing close to OD 2.0.

Both Pt12 and Pt13 bacteria were positive for IAA production in the assays using TSA broth supplemented with L-tryptophan. With $1 \mathrm{~g}$. L $\mathrm{L}^{-1}$ of L-tryptophan, a weak pink coloration formed around the bacterial colonies, and an enhanced coloration formed with $3 \mathrm{~g}$. $\mathrm{L}^{-1}$ of L-tryptophan (data not shown). The quantitative colorimetric methodology using TS-tryptophan broth $\left(0.2 \mathrm{~g} \mathrm{~L}^{-1}\right.$ and $3 \mathrm{~g} \mathrm{~L}^{-1} \mathrm{~L}$-tryptophan) also confirmed Pt12 and P13 as IAA-producing bacteria, but

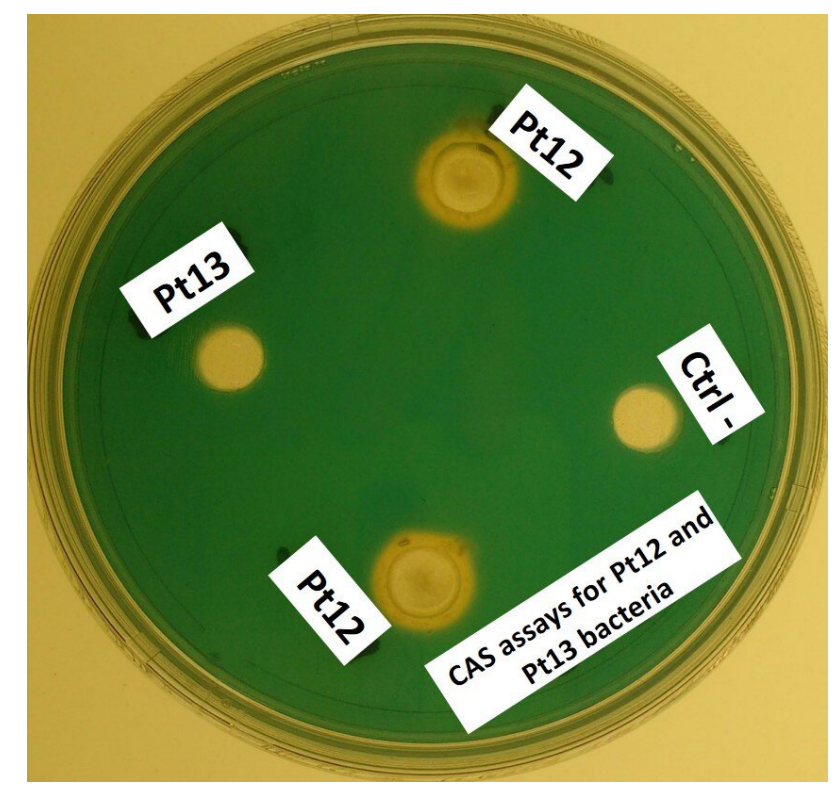

Figure 1. CAS agar medium assays for detection of siderophores in supernatants from Pt12 and Pt13 Pseudomonas cultures. As negative control (Ctrl-), we used LB broth without bacterium inoculation. The formation of a yellow-orange halo around the well is positive for siderophore production. This figure is in color in the electronic version.

Table 1. Evaluation of siderophore production and phosphate solubilization by Pt12 and Pt13 Pseudomonas bacteria. Production of siderophores in CAS solution with bacterial growth in LB broth and sampling at 24, 48, 72, 96 and $120 \mathrm{~h}$. Phosphate solubilization with bacterial growth in NBRIP medium and samplings at $24,48,72$ and $96 \mathrm{~h}$. ND = not determined.

\begin{tabular}{|c|c|c|c|c|}
\hline \multirow[b]{2}{*}{ Strain } & \multirow{2}{*}{$\begin{array}{l}\text { Growth time } \\
\text { (hours) }\end{array}$} & \multirow{2}{*}{$\begin{array}{c}\text { Siderophore } \\
\text { production } \\
\text { (SU\%) }\end{array}$} & \multicolumn{2}{|c|}{ Phosphate solubilization } \\
\hline & & & $\mathrm{PO}_{4}^{-}\left(\mu \mathrm{g} \mathrm{mL}^{-1}\right)$ & $\mathrm{pH}$ \\
\hline \multirow[t]{5}{*}{ Pt12 } & 24 & $19.69 \pm 0.61$ & $40.38 \pm 1.36$ & 4.31 \\
\hline & 48 & $20.48 \pm 0.58$ & $56.08 \pm 0.10$ & 3.99 \\
\hline & 72 & $24.27 \pm 2.46$ & $56.56 \pm 0.10$ & 4.18 \\
\hline & 96 & $27.28 \pm 2.36$ & $56.14 \pm 0.27$ & 4.31 \\
\hline & 120 & $31.02 \pm 1.98$ & & \\
\hline \multirow[t]{5}{*}{ Pt13 } & 24 & ND & ND & 6.16 \\
\hline & 48 & ND & ND & 5.89 \\
\hline & 72 & ND & ND & 6.39 \\
\hline & 96 & ND & ND & 6.31 \\
\hline & 120 & ND & & \\
\hline
\end{tabular}


with different performance in the two concentrations of L-tryptophan (Figure 3). With $0.2 \mathrm{~g} \mathrm{~L}^{-1}$ of L-tryptophan, IAA production by Pt13 was significantly higher than by Pt12 according to the SNK test $(\mathrm{p}<0.01)$ (Figure $3 \mathrm{a})$. The presence or absence of $P$. nigrum extract had no influence on IAA production. Pt13 produced IAA at all sampling times, with a maximum value near $25 \mu \mathrm{g} \mathrm{m} \mathrm{L}{ }^{-1}$ produced Pt13ext at $48 \mathrm{~h}$. From 72 to $120 \mathrm{~h}$ the IAA production of both Pt13 and Pt13ext gradually decreased. Pt12 showed no production of IAA at 24 and $48 \mathrm{~h}$, while at $120 \mathrm{~h} \mathrm{Pt12ext} \mathrm{produced} \mathrm{about}$ $10 \mu \mathrm{g} \mathrm{mL}{ }^{-1}$. Thus, Pt13 cultured in TS broth supplemented with $0.2 \mathrm{~g} \mathrm{~L}^{-1}$ of L-tryptophan and P. nigrum extract showed
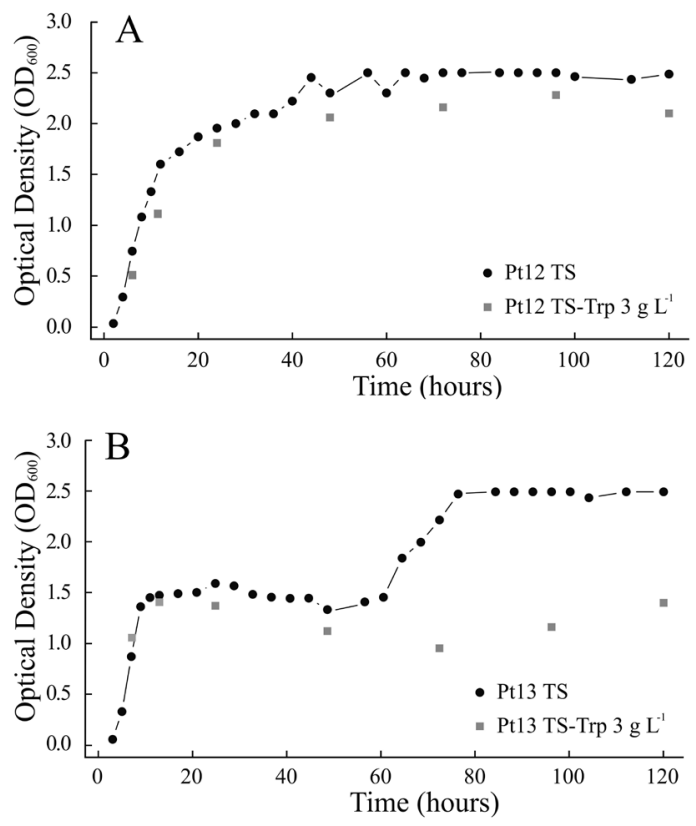

Figure 2. Growth curves of isolates Pt12 (A) and Pt13 (B) cultured in TS broth (Pt12 TS and Pt13 TS, respectively) for 120 hours, with bacterial growth monitored by optical density at $600 \mathrm{~nm}\left(\mathrm{OD}_{600}\right)$. OD values of isolates Pt12 and Pt13 cultured in TS broth supplemented with $3 \mathrm{~g} \mathrm{~L}^{-1}$ of L-tryptophan (Pt12TS-Trp $3 \mathrm{~g} \mathrm{~L}^{-1}$ and Pt13TS-Trp $3 \mathrm{gL}^{-1}$, respectively), with samplings at $6,12,24,48,72,96$ and $120 \mathrm{~h}$, are shown. a $150 \%$ difference in IAA production at $48 \mathrm{~h}$ in comparison to Pt12 at $120 \mathrm{~h}$.

With $3 \mathrm{~g} \mathrm{~L}^{-1}$ of L-tryptophan, Pt12 and Pt13 produced IAA at all sampling times (Figure $3 \mathrm{~b}$ ). The addition of the plant extract positively influenced IAA production by $\mathrm{Pt} 12$ and Pt13 during the first hours of bacterial growth (from 6 to $72 \mathrm{~h}$ for Pt12 and from 6 to $24 \mathrm{~h}$ for Pt13). IAA production by Pt12ext was significantly higher than Pt13ext at most sampling times $(48,72,96$ and $120 \mathrm{~h}$ ), while at 6 and $24 \mathrm{~h}$ no significant difference was found, and at $12 \mathrm{~h}$ Pt13ext produced more IAA than Pt12ext. Maximum IAA production by P12ext was about $125 \mu \mathrm{g} \mathrm{mL}^{-1}$ at $72 \mathrm{~h}$, and $110 \mu \mathrm{gL}^{-1}$ at $96 \mathrm{~h}$ by Pt12, with no effect of the plant extract. IAA production decreased for both Pt12 and Pt12ext at $120 \mathrm{~h}$, with no significant difference between them. Maximum IAA production by Pt13ext was 90 $\mu \mathrm{g} \mathrm{mL} \mathrm{m}^{-1}$ at $24 \mathrm{~h}$, while at $48 \mathrm{~h}$ IAA production by $\mathrm{Pt} 13$ and Pt13ext showed no significant difference. From 72 to 120 h, IAA production by Pt13ext was significantly lower than by Pt13. The highest IAA production by Pt12 (Pt12ext with $3 \mathrm{~g}$ $\mathrm{L}^{-1}$ of L-tryptophan at $72 \mathrm{~h}$ ) was $39 \%$ higher than that of Pt13 ( Pt13ext with $3 \mathrm{~g} \mathrm{~L}^{-1}$ at $24 \mathrm{~h}$ ). The addition of plant extract significantly increased IAA production by $52 \%$ in Pt13 at 24 $\mathrm{h}$, and by $78 \%$ in Pt12 at $72 \mathrm{~h}$.

\section{Phosphate solubilization}

Pt12 was able to induce the formation of translucent halos around the wells containing bacterial cells, with an average SI of 2.67. Pt13 was negative for phosphate solubilization. In the quantitative assays using liquid NBRIP, again, only Pt 12 was positive (Table 1). We detected changes in $\mathrm{pH}$ neutrality of the NBRIP medium used for both bacteria. Minimum $\mathrm{pH}$ for Pt12 was 3.99 at $48 \mathrm{~h}$, when an increase in phosphate solubilization was detected relative to $24 \mathrm{~h}$. The values of solubilization remained stable until $96 \mathrm{~h}$. Minimum $\mathrm{pH}$ for Pt13 was 5.89 at $48 \mathrm{~h}$, although no samples were positive for phosphate solubilization at any time (Table 1).
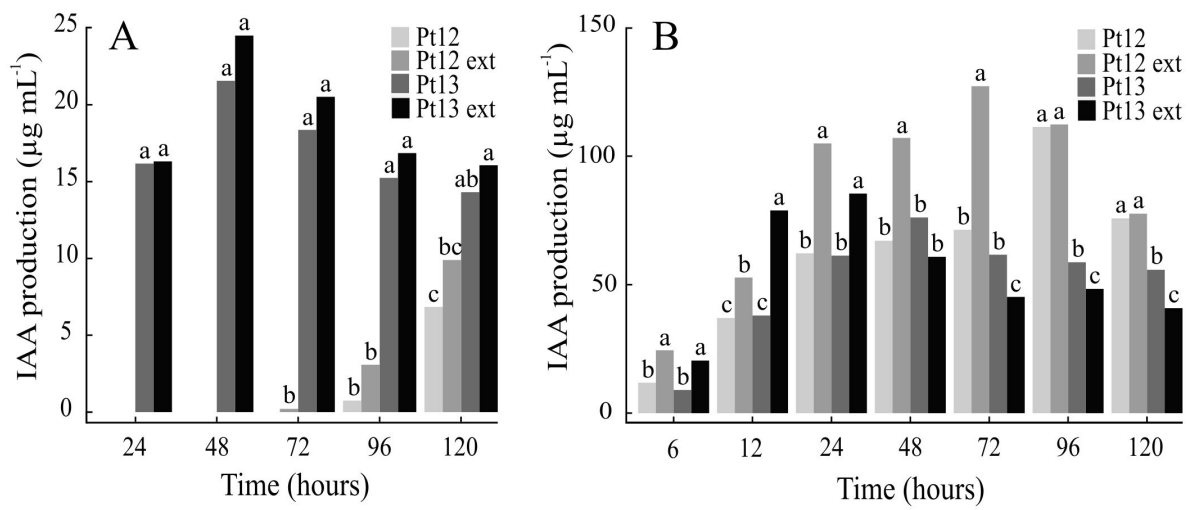

Figure 3. IAA production by Pt12 and Pt13 Pseudomonas bacteria cultured in TS broth supplemented with $0.2 \mathrm{~g} \mathrm{~L}^{-1}(\mathrm{~A})$ and $3 \mathrm{~g} \mathrm{~L} \mathrm{~L}^{-1}$ of L-tryptophan (B) with and without Piper nigrum extract for 120 hours. Assays were performed in triplicate at each sampling time, compared with SNK tests. Same letters on the bars within time points indicate non-significant differences. 


\section{DISCUSSION}

Some Amazonian Piperaceae were identified with resistance to infection by $F$. solani f. sp. piperis (Albuquerque $e t$ al. 2001), leading to the isolation of some endophytic bacteria from roots of $P$. tuberculatum, including Pseudomonas isolates Pt12 and Pt13, which were able to inhibit the in vitro growth of $F$ solani f. sp. piperis (Nascimento et al. 2015). Here, we showed that the Pt12 and Pt13 isolates differed in their ability to produce siderophores and IAA and to solubilize phosphates.

Regarding the production of siderophores, only isolate Pt12 was positive in qualitative and quantitative assays with CAS reagent. Siderophores are ferric chelating agents with low molecular weight (500-1000 Da) produced by bacteria and play a vital role in the control of several plant diseases, including some advantages over chemical fungicides (Sayyed and Chincholkar 2009). They can control pathogens by mechanisms of competition, restricting the iron nutrition of these organisms (Susi et al. 2011; Khan et al. 2017) and by inhibition of their enzymes (Benitez et al. 2004). In addition, the production of siderophores by bacteria may stimulate plant growth by improvement of their iron nutrition (Masalha et al. 2000; Sharma et al. 2003). The production of siderophores by bacteria occurs under iron-limiting conditions (Saha et al. 2016) and was also analyzed using LB broth (Arora and Verma 2017). We showed that Pt12 cells were able to release iron chelators in LB broth. Siderophore production by Pt 12 increased during bacterial growth, with maximum SU\% of 31.02 at $120 \mathrm{~h}$, which agrees with Verma et al. (2016), who reported some fluorescent Pseudomonas sp. isolates able to produce siderophores ranging from SU\% 4.68 to 42.18 .

Unlike Pt12, Pt13 was not able to produce siderophores. The CAS agar medium is widely used to detect siderophoreproducing bacteria, however, when used alone, it may generate false negatives for some non-halo producing bacterial strains, which may be positive in CAS liquid solution (Alexander and Zuberer 1991). Pt13 was not able to produce siderophores, even using CAS liquid solution. Besides LB broth, we also tested Pt12 and Pt13 in 1/5 TS broth and found similar results to those with LB broth (data not shown), indicating that only Pt12 is a siderophore producer. Siderophores produced by several bacteria, including Pseudomonas strains, have been described to have a role in the control of phytopathogens (Sulochana et al. 2014; Yu et al. 2017). Thus, it is possible that siderophores produced by $\mathrm{Pt} 12$ participate in mechanisms controlling pathogens, including the inhibition of $F$ solani f. sp. piperis growth reported by Nascimento et al. (2015). However, due to the diversity of chemical and biological structures of known siderophores (Hider and Kong 2010), further studies are necessary to isolate and characterize the siderophores produced by Pt12. Besides siderophores, bacterial endophytes may produce other compounds and molecules with enzymatic and antimicrobial activity in pathogen control (Santoyo et al. 2016; Maksimov et al. 2018).

We also detected the ability of Pt12 and Pt13 to produce IAA through qualitative and quantitative methods. Among the phytohormones, IAA is the main auxin involved in root growth (Tanimoto 2005) and is produced by several PGPB, including Pseudomonas strains (Egamberdieva et al. 2015; Hidri et al. 2016). Bacteria may produce IAA through tryptophan-dependent and tryptophan-independent means, tryptophan probably being the main IAA precursor in most of them (Zhang et al. 2019). Although some bacteria are able to synthesize IAA through a tryptophan-independent pathway (Duca et al. 2014; Arora and Bae 2014), this route is still poorly known. We used two concentrations of L-tryptophan in TS broth, resulting in differential performance of Pt12 and Pt13 in IAA production, but both strains showed higher IAA production under higher concentration of tryptophan, indicating that both probably produce IAA through a tryptophan-dependent biosynthesis pathway. Bacteria may produce IAA through four main tryptophan-dependent pathways: indole-3-pyruvate (IPA), tryptamine (TPM), indole-3-acetonitrile (IAN), and indole-3-acetamide (IAM) (Zhang et al. 2019). Genome studies showed that $68.5 \%$ and $11.9 \%$ of Proteobacteria can catalyze tryptophan into IPA and TPM, respectively (Zhang et al. 2019). So, it is probable that Pt12 and Pt13 utilize these pathways for IAA production. Our results also showed that most Pt12 and Pt13 IAA production occurred in stationary phase, which is in accordance with other bacteria, including Pseudomonas strains (Bharucha and Kamlesh 2013; Duca et al. 2014)).

Under the two concentrations of tryptophan used here, Pt12 showed a higher amino acid requirement for IAA production. Even bacteria able to produce IAA in the absence of tryptophan had increased activity for the production of indole compounds when the amino acid was added to the culture medium (Jayaprakashvel et al. 2014). Pseudomonas bacteria increased IAA production from 80 to $132 \mu \mathrm{g} \mathrm{mL} \mathrm{L}^{-1}$ when L-tryptophan supplementation was changed from 0.1 to $0.5 \mathrm{~g} \mathrm{~L}^{-1}$ (Sasirekha et al. 2012). Etminani and Harighi (2018) identified Pseudomonas protensensis from Pistacia atlantica L. that were able to produce IAA in amounts of 8 to $50 \mu \mathrm{g} \mathrm{mL} \mathrm{m}^{-1}$. Pseudomonas putida and P. fuorescens produced 116 and 89 $\mu \mathrm{g} \mathrm{mL} \mathrm{L}^{-1}$ of IAA, respectively (Meliani et al. 2017). The Pt13 Pseudomonas in our study produced similar IAA amounts to those produced by other Pseudomonas bacteria, while Pt 12 produced little IAA in the presence of a low concentration of the amino acid.

The ability of Pt12 and Pt13 to produce IAA indicated their potential as PGBP, considering that the capacity of Pt13 to promote the growth of $P$. nigrum plants through the improvement of their root system was already demonstrated by Pereira $e t$ al. (2019). 
In this context, the positive effect of $P$. nigrum extract in optimizing the physiology of Pt12 and Pt13 regarding their ability to produce IAA, supports these bacteria as promising candidates in the interaction with this crop. Plant extracts containing metabolites and other substances can stimulate IAA production by bacteria (Jasim et al. 2014; Kamilova et al. 2006). In addition, plant and endophyte gene expression may be changed during their interaction (Santoyo et al. 2016), so that it is possible that metabolites of $P$. nigrum affected the expression of Pt12 and Pt13 genes related to IAA synthesis, causing the observed increase in IAA production. Although Pt12 and Pt13 were isolated from P. tuberculatum (Nascimento et al. 2015), here we used the extract from P. nigrum, which is the crop affected by root rot disease. The addition of the plant extract increased the in vitro production of IAA from $42 \%$ to $106 \%$ between 6 and $72 \mathrm{~h}$ for Pt 12 , and from $52 \%$ to $126 \%$ between 6 and $24 \mathrm{~h}$ for Pt13. However, over a longer period, we found no influence of the plant extract, e.g. Pt12 at 96 and $120 \mathrm{~h}$, when the addition of the plant extract had no effects. Although we do not have sufficient data to clarify what exactly caused this result, some possibilities can be considered. The plant extract used in the first hours of bacterial growth may have become unavailable in the later hours. Besides, since it is known that some plant extracts may enhance the growth of microorganisms (Eevers et al. 2015), so that it is possible that the growth of Pt12 and Pt13 was accelerated by the $P$. nigrum extract, and more rapidly reached the declining phase, when the production of IAA-degrading enzymes may occur. Likewise, the decrease of IAA in Pt13 samples from 72 to 120 $\mathrm{h}$ may be due to the production of IAA-degrading enzymes when the bacterial growth comes close to the end of the stationary phase. Under certain circumstances, bacteria may utilize IAA as carbon and energy sources (Arora et al. 2015).

The presence of L-tryptophan in TS broth $\left(3 \mathrm{~g} \mathrm{~L}^{-1}\right)$ caused a decrease in Pt12 and Pt13 growth in comparison to their growth in TS broth. Bacterial growth can be inhibited by tryptophan (Brandenburg et al. 2013), but the mechanism of inhibition is not clear so far. Each bacterial strain has a specific need and specific amino acid resistance, and an excess causes inhibition by killing the plant-associated bacteria rather than promoting plant growth (Barazani and Friedman 2000). It is probable that this effect interfered with IAA production of Pt13, as its growth was drastically affected by tryptophan. It was higher than that of Pt 12 with $0.2 \mathrm{~g} \mathrm{~L}^{-1} \mathrm{~L}$-tryptophan, but lower than Pt12 growth with $3 \mathrm{~g} \mathrm{~L}^{-1} \mathrm{~L}$-tryptophan. Besides growth sensitivity to tryptophan, another characteristic of Pt13 was its biphasic pattern, similar to diauxic growth, when cultured in TS broth. Diauxic growth is characterized by bi-phasic exponential growth intermitted by a lag phase, and it generally occurs when microorganisms are cultured in two carbon sources, such as glucose and lactose (Narang and Pilyugin 2007). Diauxic growth has been described in many bacteria, including Pseudomonas strains, when submitted to glucose and other substances, such as organic acids (Lynch and Franklin 1978), aromatic compounds (Basu et al. 2009) and phenylpropanoid compounds (Karishma et al. 2015), among other conditions, such as variation of $\mathrm{pH}$ and temperature. As far as we know, this is the first time that a Pseudomonas bacterium has been reported showing diauxic growth in TS broth. Physiological and genetic traits inherent to each bacterial strain may contribute to the occurrence of diauxic growth, which involves metabolic responses of bacteria to nutritional conditions, among other environmental variations (Narang and Pilyugin 2007). Additional studies are needed to clarify the factors involved in diauxic growth in Pt13.

Only isolate Pt 12 was positive for phosphate solubilization in our qualitative and quantitative assays. After nitrogen, phosphorus is considered the second most important nutrient for plants, and, although phosphorus is abundant in most soils used in agriculture, it is frequently found in an insoluble state (Miller et al. 2010). Thus, solubilizing phosphates by bacteria is an alternative for making phosphorus available to plants in the soil, or at least avoiding losses in fertilization practices. The process of phosphate solubilization by bacteria involves the production of organic acids, which solubilize phosphates by converting them into orthophosphate, which is available for plant use (Oteino et al. 2015).

The screening of phosphate solubilizing bacteria is generally performed in solid media, but this is not the most appropriate and efficient method for evaluating solubilizing activity, nor for indicating the potential solubilizing bacteria, because some bacterial strains do not solubilize phosphates in solid medium, although they can in liquid medium (Nautiyal 1999; Zeng et al. 2016). Here, Pt12 showed the ability to produce transparent halos around the bacterial colony grown in NBRIP agar medium, with a solubilization index of 2.67, that is consistent with values ranging from 1.08 to 2.74 reported by other studies (Kaur et al. 2017; Georgieva et al. 2018).

The $\mathrm{pH}$ of the NBRIP medium of Pt12 samples ranged from 3.99 ( $24 \mathrm{~h}$ ) to $4.31(96 \mathrm{~h})$ and production of soluble phosphate ranged from 40.38 to $56.56 \mu \mathrm{g} \mathrm{mL}^{-1}$. At $48 \mathrm{~h}$, when the $\mathrm{pH}$ decreased the most, there was a significant increase in phosphate solubilization. Pseudomonas strains were able to solubilize $\mathrm{Ca}_{3}\left(\mathrm{PO}_{4}\right)_{2}$ in liquid NBRIP medium, producing from 27.16 to $110.28 \mu \mathrm{g} \mathrm{mL}^{-1}$ of phosphorus when the $\mathrm{pH}$ of the medium fell (Zeng et al. 2016; Ordoñez et al. 2016). During bacterial growth, the release of substances such as enzymes or organic acids acidifies the medium, allowing the solubilization of insoluble phosphate, thus, the release of water-soluble phosphorus has been directly proportional to the acidification of the medium (Zeng et al. 2016; Satyaprakash et al. 2017). Unlike Pt12, Pt13 showed no ability to produce transparent halos around the bacterial colonies grown in NBRIP agar medium, showing no ability to solubilize 
phosphate, with $\mathrm{pH}$ ranging from 5.89 to 6.39 between 24 and $96 \mathrm{~h}$. Our results are in accordance with other studies showing bacteria with different ability to solubilize phosphate. Among the bacteria with the ability to solubilize phosphate, P. fluorescens (L111) produced $438 \mathrm{mg} \mathrm{L}^{-1}$ of phosphorus and changed the $\mathrm{pH}$ of the medium to 4.96 , while P. fluorescens (L228) was able to produce $1.312 \mathrm{mg} \mathrm{L}^{-1}$ of phosphorus and changed the $\mathrm{pH}$ of the medium to 4.06 (Oteino et al. 2015). On the other hand, Bacillus sp. changed the $\mathrm{pH}$ of the medium to 5.28 and solubilized $85 \mathrm{mg} \mathrm{L}^{-1}$ of phosphorus and was able to produce gluconic acid proportionally to the phosphate solubilization of each bacterium (Oteino et al. 2015). Similarly, our results with Pt12 and Pt13 confirmed that bacteria with a higher capacity to acidify the medium were better phosphate solubilizers.

\section{CONCLUSIONS}

We showed that Psendomonas bacteria of Piper tuberculatum differ in their ability to produce siderophores, IAA and phosphate solubilization, which are important bio-stimulating compounds for plant development. Pseudomonas putida Pt12 was able to solubilize inorganic phosphate, as well as producing IAA and siderophores, supporting its potential as a PGPB. Likewise, the ability of Pseudomonas sp. Pt13 to produce IAA confirms its role as a PGPB, previously demonstrated for Piper nigrum as its host plant. The ability of Pt12 and Pt13 to synthesize IAA, mainly under high concentration of L-tryptophan, indicated that they are IAA-producing bacteria, probably through a tryptophan-dependent biosynthesis pathway. Furthermore, the presence of $P$. nigrum extract positively influenced the IAA production by Pt12 and Pt13.

\section{ACKNOWLEDGMENTS}

The authors thank Conselho Nacional de Desenvolvimento Científico e Tecnológico (CNPq), Coordenação de Aperfeiçoamento de Pessoal de Nível Superior (CAPES), Fundação Amazônia de Amparo a Estudos e Pesquisas do Pará, Universidade Federal Rural da Amazônia (UFRA) and Universidade Federal do Pará (UFPA).

\section{REFERENCES}

Albuquerque, F.C.; Duarte, M.L.R.; Benchimol, R.L.; Endo, T. 2001. Resistência de piperáceas nativas da Amazônia à infecção causada por Nectria haematococca f. sp. piperis. Acta Amazonica, 31: 341-348.

Alexander, D.B.; Zuberer, D.A. 1991. Use of chrome azurol S reagents to evaluate siderophore production by rhizosphere bacteria. Biology and Fertility of Soils, 12: 39-45.

Arora, P.K.; Bae, H. 2014. Identification of new metabolites of bacterial transformation of indole by gas chromatography-mass spectrometry and high performance liquid chromatography. International Journal of Analytical Chemistry, 2014: 239641.
Arora, P.K.; Sharma, A.; Bae, H. 2015. Microbial degradation of indole and its derivatives. Journal of Chemistry, 2015: 129159.

Arora, N.K.; Verma, M. 2017. Modified microplate method for rapid and efficient estimation of siderophore produced by bacteria. 3 Biotech, 7: 381. doi: 10.1007/s13205-017-1008-y.

Barazani, O.; Friedman, J. 2000. Effect of exogenously applied $\mathrm{L}$-tryptophan on allelochemical activity of plant-growthpromoting rhizobacteria (PGPR). Journal of Chemical Ecology, 26: 343-349.

Basu, A.; Das, D.; Bapat, P.; Wangikar, P.P.; Phale, P.S. 2009. Sequential utilization of substrates by Pseudomonas putida CSV86: Signatures of intermediate metabolites and online measurements. Microbiological Research, 164: 429-37.

Beneduzi, A., Ambrosini, A., Passaglia, L.M.P. 2012. Plant growth-promoting rhizobacteria (PGPR): Their potential as antagonists and biocontrol agents. Genetics Molecular Biology, 35: 1044-1051.

Benitez, T.; Rincón, A.; Limón, M.C.; Codon, A. 2004. Biocontrol mechanisms of Trichoderma strains. International Microbiology, 7: 249-260.

Bharucha, U.; Kamlesh, P. 2013. Optimization of indole acetic acid production by Pseudomonas putida UB1 and its effect as plant growth-promoting rhizobacteria on mustard (Brassica nigra). Agricultural Research, 2: 215-221.

Brandenburg, K.S.; Rodriguez, K.J.; McAnulty, J.F.; Murphy, C.J.; Abbott, N.L.; Schurr, M.J.; Czuprynski, C.J. 2013. Tryptophan inhibits biofilm formation by Pseudomonas aeruginosa. Antimicrobial Agents and Chemotherapy, 57: 1921-1925.

Bric, J.M.; Bostock, R.M.; Silverstonet, S.E. 1991. Rapid in situ assay for indoleacetic acid production by bacteria immobilized on a nitrocellulose membrane. Applied and Environmental Microbiology, 57: 535-538.

Chalita, P.B.; Farias, E.N.C.; Costa I.B.; Sousa, B.F.; Santos, M.A.O.; Albuquerque, T.C.S.; Vital, M.J.S.; Silva, K. 2019. Characterization of bacterial endophytes from the roots of native and cultivated Brazil nut trees (Bertholletia excelsa). Acta Amazonica, 49: 257-267.

Coêlho, M.M.; Ferreira-Nozawa, M.S.; Nozawa, S.R.; Santos, A.L.W. 2011. Isolation of endophytic bacteria from arboreal species of the Amazon and identification by sequencing of the 16S rRNA encoding gene. Genetics and Molecular Biology, 34: 676-680.

Duca, D.; Lorv, J.; Patten, C.L.; Rose, D.; Glick, B.R. 2014. Indole-3-acetic acid in plant-microbe interactions. Antonie Van Leeuwenhoek, 106: 5-125.

Eevers, N.; Gielen, M.; Sánchez-López, A.; Jaspers, S.; White, J. C.; Vangronsveld, J.; Weyens, N. 2015. Optimization of isolation and cultivation of bacterial endophytes through addition of plant extract to nutrient media. Microbial Biotechnology, 8(4): $707-715$.

Egamberdieva, D.; Jabborova, D.; Hashem, A. 2015. Pseudomonas induces salinity tolerance in cotton (Gossypium hirsutum) and resistance to Fusarium root rot through the modulation of indole3-acetic acid. Saudi Journal of Biological Sciences, 22: 773-779. 
Etminani, F.; Harighi, B. 2018. Isolation and identification of endophytic bacteria with plant growth promoting activity and biocontrol potential from wild pistachio trees. Plant Pathology Journal, 34: 208-217.

Gaiero, J.R.; McCall, C.A.; Thompson, K.A.; Day, N.J.; Best, A.S.; Dunfield, K.E. 2013. Inside the root microbiome: bacterial root endophytes and plant growth promotion. American Journal of Botany, 100: 1738-1750.

Georgieva, T.; Evstatieva, Y.; Savov, V.; Bratkova, S.; Nikolova, D. 2018. Assessment of plant growth promoting activities of five rhizospheric Pseudomonas strains. Biocatalysis and Agricultural Biotechnology, 16: 285-292.

Glick, B.R. 1995. The enhancement of plant growth by free-living bacteria. Canadian Journal of Microbiology, 41: 109-117.

Glick, B.R. 2012. Plant growth-promoting bacteria: mechanisms and applications. Scientifica, 2012: 963401.

Gordon, S.A.; Weber, R.P. 1951. Colorimetric estimation of indoleacetic Acid. Plant Physiology, 26: 192-195.

Hallmann, J.; Quadt-Hallmann, A.; Mahaffee, W.F.; Kloeppe, J.W. 1997. Bacterial endophytes in agricultural crops. Canadian Journal of Microbiology, 43: 895-914.

Hider, R.C.; Kong, X. 2010. Chemistry and biology of siderophores. Natural Product Reports, 27: 637-657.

Hidri, R.; Barea, J.M.; Mahmoud, O.M.; Abdelly, C.; Azcón, R. 2016. Impact of microbial inoculation on biomass accumulation by Sulla carnosa provenances, and in regulating nutrition, physiological and antioxidant activities of this species under non-saline and saline conditions. Journal of Plant Physiology, 201: 28-41.

Jasim, B.; Jimtha, J.C.; Shimil, V.; Jyothis, M.; Radhakrishnan, E.K. 2014. Studies on the factors modulating indole-3-acetic acid production in endophytic bacterial isolates from Piper nigrum and molecular analysis of ipdc gene. Journal of Applied Microbiology, 117: 786-799.

Jayaprakashvel, M.; Abishamala, K.; Periasamy, C.; Satheesh, J.; Hussain, A.J.; Vanitha, M.C. 2014. Isolation and characterization of indole acetic acid (IAA) produced by a halo tolerant marine bacterium isolated from coastal sand dune plants. Biosciences Biotechnology Research Asia, 11: 263-269.

Kamilova, F.; Kravchenko, L.V.; Shaposhnikov, A.I.; Azarova, T.; Makarova, N.; Lugtenberg, B. 2006. Organic acids, sugars and L-tryptophane in exudates of vegetables growing on stonewool and their effects on activities of rhizosphere bacteria. Molecular Plant-Microbe Interactions, 19: 250-256.

Karishma, M.; Trivedi, V.D.; Choudhary, A.; Mhatre, A.; Kambli, P.; Desai, J.; Phale, P.S. 2015. Analysis of preference for carbon source utilization among three strains of aromatic compounds degrading Pseudomonas. FEMS Microbiology Letters, 362: fnv139.

Kaur, G.; Sharma, P.; Chhabra, D.; Chand, K.; Mangat, G.S. 2017. Exploitation of endophytic Pseudomonas sp. for plant growth promotion and colonization in rice. Journal of Applied and Natural Science, 9: 1310-1316.

Khan, A.; Singh, P.; Srivastava, A. 2017. Synthesis, nature and utility of universal iron chelator- Siderophore: A review. Microbiological Research, 212-213: 103-111.
Lynch, W.L.; Franklin, M. 1978. Effect of temperature on diauxic growth with glucose and organic acids in Pseudomonas fluorescens. Archives of Microbiology, 118: 133-140.

Maksimov, I.V.; Maksimova, T.I.; Sarvarova, E.R.; Blagova, D.K. 2018. Endophytic bacteria as effective agents of new-generation biopesticides (Review). Applied Biochemistry and Microbiology, 54: $128-140$.

Masalha, J.; Kosegarten, H.; Elmaci, Ö.; Menge, K. 2000. The central role of microbial activity for iron acquisition in maize and sunflower. Biology and Fertility of Soils, 30: 433-439.

Meliani, A.; Bensoltane, A.; Benidire, L.; Oufdou, K. 2017. Plant growth-promotion and IAA secretion with Pseudomonas fluorescens and Pseudomonas putida. Research \& Reviews: Journal of Botanical Sciences, 6: 16-24.

Miller, S.H.; Browne, P.; Prigent-Cambaret, C.; Combes-Meynet, E.; Morrissey, J.P.; O'Gara, F. 2010. Biochemical and genomic comparison of inorganic phosphate solubilisation in Pseudomonas species. Environmental Microbiology Reports, 2: 403-411.

Murphy, J.; Riley, J.P. 1962. A modified single solution method for the determination of phosphate in natural waters. Analytical Chemistry Acta, 27: 31-36.

Narang, A.; Pilyugin, S.S. 2007. Bacterial gene regulation in diauxic and non-diauxic growth. Journal of Theoretical Biology, 244: 326-48.

Nascimento, S.B.; Lima, A.M.; Borges, B.N.; de Souza, C.R.B. 2015. Endophytic bacteria from Piper tuberculatum Jacq.: isolation, molecular characterization, and in vitro screening for the control of Fusarium solani f. sp. piperis, the causal agent of root rot disease in black pepper (Piper nigrum L.). Genetics and Molecular Research, 14: 7567-7577.

Nautiyal, C.S. 1999. An efficient microbiological growth medium for screening phosphate solubilizing microorganisms. FEMS Microbiology Letters, 170: 265-270.

Nguyen, C.; Yan, W.; Le Tacon, F.; Lapeyrie, F. 1992. Genetic variability of phosphate solubilizing activity by monocaryotic and dicaryotic mycelia of the ectomycorrhizal fungus Laccaria bicolor (Maire) P.D. Orton. Plant Soil, 143: 193-199.

Olanrewaju, O.S.; Glick, B.R.; Babalola, O.O. 2017. Mechanisms of action of plant growth promoting bacteria. World Journal of Microbiology and. Biotechnology, 33: 197. doi: 10.1007/s11274017-2364-9.

Ordoñez, Y.M.; Fernandez, B.R.; Lara, L.S.; Rodriguez, A.; Uribe-Vélez, D.; Sanders, I.R. 2016. Bacteria with phosphate solubilizing capacity alter mycorrhizal fungal growth both inside and outside the root and in the presence of native microbial communities. PLosOne, 11: e0154438.

Oteino, N.; Lally, R.D.; Kiwanuka, S.; Lloyd, A.; Ryan, D.; Germaine, K.J.; Dowling, D.N. 2015. Plant growth promotion induced by phosphate solubilizing endophytic Pseudomonas isolates. Frontiers in Microbiology, 6: 745. doi: 10.3389/ fmicb. 2015

Pereira, A.C.C.; Castro, G.L.S.; Rodrigues, P.C.; Silva, G.B.; Oliveira, D.A.; de Souza, C.R.B. 2019. An endophytic Pseudomonas sp. of Piper tuberculatum promotes growth on Piper nigrum through increase of root biomass production. Physiological and Molecular Plant Pathology, 108: 101420. 
Saha, M.; Sarkar, S.; Sarkar, B.; Sharma, B.K.; Bhattacharjee, S.; Tribedi, P. 2016. Microbial siderophores and their potential applications: a review. Environmental Science and Pollution Research, 23: 3984-3999.

Santoyo, G.; Moreno-Hagelsieb, G.; Orozco-Mosqueda, M.C.; Glick, B.R. 2016. Plant growth promoting bacterial endophytes. Microbiological. Research, 183: 92-99.

Sasirekha, B.; Shivakumar, S.; Sullia, S.B. 2012. Statistical optimization for improved indole-3-acetic acid (IAA) production by Pseudomonas aeruginosa and demonstration of enhanced plant growth promotion. Journal of Soil Science and Plant Nutrition, 12: $863-873$.

Satyaprakash, M.; Nikitha, T.; Reddi, E.U.B.; Sadhana, B.; Vani, S.S. 2017. Phosphorous and phosphate solubilizing bacteria and their role in plant nutrition. International Journal of Current Microbiology and Applied Sciences, 6: 2133-21446.

Sayyed, R.Z.; Chincholkar, S.B. 2009. Siderophore-producing Alcaligenes feacalis exhibited more biocontrol potential vis-à-vis chemical fungicide. Current Microbiology, 58: 47-51.

Schwyn, B.; Neilands, J.B. 1987. Universal chemical assay for the detection and determination of siderophore. Analytical Biochemistry, 160: 47-56.

Sharma, A.; Johri, B.N.; Sharma, A.K.; Glick, B.R. 2003. Plant growth-promoting bacterium Pseudomonas sp. strain GRP3 infuences iron acquisition in mung bean (Vigna radiata L. Wilzeck). Soil Biology and Biochemistry, 35: 887-894.

Silva Junior, O.S.; Barros, N.L.F.; Siqueira, A.S.; Gonçalves, E.C.; Marques, D.N.; Reis, S.P.; de Souza, C.R.B. 2018. Detection of sequences related to biosynthesis of antifungal metabolites and identification of a PhzF-like gene in a Pseudomonas rhizobacterium of Piper tuberculatum. Genetics and Molecular Research, 17: gmr18035.

Sulochana, M.B.; Jayachandra, S.Y.; Kumar, S.K.A.; Dayanand, A. 2014. Antifungal attributes of siderophore produced by the
Pseudomonas aeruginosa JAS-25. Journal of Basic Microbiology, 54: 418- 424

Susi, P.; Aktucanov, G.; Himanen, J.; Korpela, T. 2011. Biological control of wood decay against fungal infection. Journal of Environmental Management, 92: 1681-1689.

Tanimoto, E. 2005. Regulation of root growth by plant hormones: roles for auxin and gibberellin. Critical Review in Plant Science, 24: 249-265.

Verma, P.; Thakur, S.; Kaur, M. 2016. Antagonism of Pseudomonas putida against Dematophora nectarix a major apple plant pathogen and its potential use as a biostimulant. Journal of Pure and Applied Microbiology, 10: 2717-2726.

Yu, S.; Teng, C.; Liang, J.; Song, T.; Dong, L.; Bai, X.; Jin, Y.; Qu, J. 2017. Characterization of siderophore produced by Pseudomonas syringae BAF.1 and its inhibitory effects on spore germination and mycelium morphology of Fusarium oxysporum. Journal of Microbiology, 55: 877-884.

Zeng, Q.; Wu, X.; Wen, X. 2016. Identification and characterization of the rhizosphere phosphate-solubilizing bacterium Pseudomonas frederiksbergensis JW-SD2, and its plant growth-promoting effects on poplar seedlings. Annals of Microbiology, 66: 1343-1354.

Zhang, P.; Jin, T.; Sahu, S.K.; Xu, J.; Shi, Q.; Liu, H.; Wang, Y. 2019. The distribution of tryptophan-dependent indole-3-acetic acid synthesis pathways in bacteria unraveled by large-scale genomic analysis. Molecules, 24: 1411. doi: 0.3390/molecules24071411.

RECEIVED: $29 / 05 / 2020$

ACCEPTED: 18/10/2020

ASSOCIATE EDITOR: Antonio R. Fernandes 